\title{
NAS FOLHAS DA CRÍTICA LITERÁRIA DOS ÚLTIMOS 40 ANOS
}

\author{
GIACON,Eliane Maria de Oliveira1 \\ RODRIGUES, Marlon Lea2,I
}

\section{1}

Quando o assunto é crítica, no Brasil, é possível dizer, que a intenção de fazer uma crítica, que leve em conta de onde partiu a obra ( momento sóciohistórico) só ganhou força depois da década de 1950. Visto que os críticos de até então focavam suas preocupações em analisar a obra literária sob o ponto de vista biográfico ou muitas vezes pelo critério de afinidade/rejeição entre o autor e o crítico. A crítica " no século XIX e primeira metade do XX, parte de "julgamentos de valor explícitos, da década de 1950 para cá novos caminhos teóricos se abriram"(MALARD, 2007,p.120) a tendências teóricas, que visam mais o texto literário do que os fatores externos. Assim o final da década de 1950 e o início da década de 1960 pode ser considerado o marco da presença da crítica universitária praticada por nomes como Lêdo Ivo.

Nos anos pós-68, forma-se por assim dizer dois blocos: um com os críticos, que pertencem a Academia Brasileira de Letras e são professores universitários das Letras; e outro que são professores universitários, mas não pertencem a ABL. A professora Letícia Malard escreveu um ensaio para a ABL, no qual ela faz um estudo sobre os 100 anos da instituição situando em cada período críticos, cujos trabalhos foram relevantes. Para efeito de localização tomar-se-á o texto a partir do período que vai entre 1967-1977 e subseqüente os outros de dez em dez anos até 2007.

O crítico da década de 1967-1977 é Eduardo Portella.[...]Portella foi o primeiro crítico que defendeu uma tese universitária sobre o assunto, intitulada "Crítica literária: método e ideologia"(1970)[...]para Portella a crítica ideológica se torna precária, da mesma forma que a crítica estruturalista - que despontava entre nós, importada da França -, a qual também não dá conta do caráter artístico da obra. Eduardo se bate por

1 Professora de Literatura da UEMS-Universidade Estadual de Mato Grosso do Sul. Doutoranda em Literatura pela UNESP (Assis/SP) - UEMS

${ }^{2}$ Marlon Leal Rodrigues (Doutor em Linguística UNICAMP - UEMS) 
uma crítica que compreenda o objeto literário como uma totalidade,o que se torna possível através do rigor de um método.(MALARD,2007p.123-124)

Num período histórico, cujas ideologias podem significar vida ou morte, a adoção da posição de Portella quanto ao esgotamento tanto da ideologia quanto do estruturalismo, por uma crítica centrada na totalidade do objeto literário, demonstra um ponto de fuga, que irá distanciar boa parte da crítica literária brasileira da sociedade e do tempo presentes.

A próxima década entre 1977-1987, encontra José Guilherme Merquior que responde pela $A B L$, cuja obra não se filia a nenhuma corrente ( Psicanálise, Estruturalismo ou Marxismo). A que mais ele se aproxima é a Estilística, visto que entre as preferências do ensaísta está na lírica "seu gênero literário preferido em matéria de crítica - e a erudição, não raro utilizada como fim em si. Merquior insere no texto abundantes citações do objeto criticado, o que consideramos positivo na crítica de divulgação, para dar ao leitor uma idéia melhor da obra."(p.125), o que caracterizará não só a sua forma de escrever como também a de muitos críticos dos próximos anos, cujos textos serão composto pela via da descrição do objeto literário, bem como a sua situação ante a história, a estética e a ideologia.

A abertura política de 1982, que se arrasta até o final dessa década, não só traz de volta os exilados e as discussões sobre identidade, como também aporta na $\mathrm{ABL}$ como o nome de Alfredo Bosi, que da mesma geração de Portella sustenta o ofício de crítico no esteio da Cultura, no tripé do "viés histórico, da perspectiva estética e da matriz ideológica.(p.126). No trabalho de Bosi, entre 1987-1997, figuram as maiores transformações da Literatura Brasileira no tocante ao mercado editorial, a cultura de massa e a influência dos medias sobre a produção literária. É possível perceber que ele mantém uma "invejável competência de adequação entre forma e conteúdo (aliás, prefere designar o conteúdo de "evento")", (Idem). O que não o furtou de escrever a História Concisa da Literatura Brasileira publicada pela Cultrix, cujo formato deixa muito a desejar, pois não há um aprofundamento dos estudos literários, contudo até hoje o livro está além da trigésima edição, atendendo a um público(cursinhos e de cursos de formação de professores) como "livro de cabeceira", sem que muitas vezes haja contato desses estudantes com outras 
Histórias da Literatura Brasileira. Um livro, que atendeu ao mercado consumidor.

Para o período entre 1997-2007, Letícia Malard cita uma característica que une os três nomes de Antônio Carlos Secchin, Domício Proença Filho e Ivan Junqueira, pois "sendo bons poetas os três, transmigram a própria sensibilidade para a sensibilidade alheia ao captarem as luzes e as trevas do texto em processo de crítica. Assim, não é gratuito o fato de os três preferirem escrever sobre obras do gênero lírico[...](p.127) corroborando para o que diz Flora Süssekind com a frase " a vingança da crítica do rodapé"

Os críticos do rodapé seguiam os ensinamentos de Machado, cuja apreciação e sensibilidade estavam acima muitas vezes dos pressupostos teóricos, logo volta a figurar na crítica praticada pela $A B L$, uma dimensão crítica que alia o professor universitário a sensibilidade do artista. Prevalecendo mais a apreciação sob a batuta da sensibilidade do que o aprofundamento teórico exigido aos críticos da segunda metade do século $X X$.

\section{2}

A partir do final dos anos 80 e da década seguintes, a crítica literária, no Brasil, não só se restringe a Academia Brasileira de Letras, mas a muitos professores universitários, que com a retomada dos congressos, encontros, simpósios, jornadas literárias, eles passam a escrever textos críticos nos anais e revistas, que passam conter estudos de nomes como Regina Zilberman, Lúcia Helena, Tânia Pellegrini, Maria Eunice Moreira.Nessa esteira seguem alguns outros nomes como Renato Franco, Walnice Nogueira Galvão,Roberto Schwartz, Silviano Santiago e Flora Süssekind, sendo a última um caso excepcional, pois na década de 1990, nas primeiras horas, ele publica em jornais estudos críticos, que pontuam a literatura daquele período.

Um deles é "Escala e Ventríloquos" publicado no Suplemento "MAIS" da Folha de São Paulo, em 23/07/2000. O texto, a princípio, parecia um pouco difuso, pois as informações sobre a produção literária, não eram em tempo real, no sentido de que para analisar o formato de um determinado momento histórico cabia ao crítico acompanhar as publicações e resenhas, que eram escritas,em jornais e revistas, diferente de hoje, que com as pontas dos dedos, o pesquisador pode saber tudo ou quase tudo sobre as publicações e críticas 
das obras literárias. Em 2000, quando Flora publica os seus estudos sobre a produção literária, daquele período, há a questão da proximidade, que dificulta o juízo de valor, que os leitores têm ao acompanhar as posições teóricas. Com o distanciamento e acesso mais fácil aos textos críticos publicados desde então, fica mais viável ao pesquisador verificar como Flora fez um inventário para separar os tipos de publicação literária e a escala de valor dada a cada uma delas.

As publicações dos críticos literários antes do período de 1968 a 1978 figuravam nos suplementos literários. No período subseqüente os suplementos literários nos jornais de grande circulação desaparecem, voltando no final da década de 1980. Contudo é interessante notar, que mesmo os que permaneceram entre 1968 e 1978 como O Galo do Paraná e Suplemento Literário de Minas Gerais, trazem em seus textos impressos, discussões críticas não votadas para autores daquele momento, mas de releitura do cânone sob a perspectiva de teorias de direita, evitando tratar de nomes como Georg Lukács, Walter Benjamin, Adorno, entre outros, cujas teorias já tinham mais de 40 anos de existência.O que é possível verificar nesse período é a predominância de estudos de autores locais tanto do Paraná como de Minas, que aparentemente não tinham conotação política em suas obras, mas sim voltados para os experimentalismos sejam linguísticos ou literários. A não opção pelos estudos dos romances daquele período não se justifica pela pouca publicação, pois o romance foi um dos meios, que menos sofreu pressão da Ditadura de 1964.

Das revistas literárias, que iniciam no período citado, ou antes, e continuam até hoje foram selecionadas a Revista de Letras da Universidade Federal do Paraná, Revista de Letras da UNESP, Letras de Hoje da PUC do Rio Grande do Sul. A Revista de Letras da Universidade Federal do Paraná, talvez seja uma das mais antigas, cuja publicação inicia em 1953, sendo anual até a edição de número 44. A partir dessa publicação, ela passa a ser semestral. Nos números pesquisados nas décadas de 1970, 1980 e 1990, verificam-se duas tendências: ora de estudos que remontam a obras anteriores a 1964 que são analisadas entre as décadas de 1970 e 1980 ora há a presença de leituras de textos literários via semiótica, estilística. Ao final dos 
anos 80 percebe-se que há a presença um pouco tímida da leitura historiográfica. Da década de 1990 em diante, a revista passa a ser um "regalo" para os olhos da modernidade, pois há a preferência por leituras mais contemporâneas, fixadas em nomes como Cristina Cesar, Paulo Leminsk, João Ubaldo Ribeiro, Lygia Bojunga Nunes, Umberto Eco. Além dos nomes é interessante notar a versatilidade da revista. Um exemplo está na revista de número 46 de 1996, na qual há estudos de Literatura Infantil, Literatura e História, bem como outros voltados para a leitura do texto literário em busca de pressupostos da Linguística.

A fragmentação aparente da revista reflete uma ligação com o tempo presente da década de 1990, vindo à tona os descaminhos e a esfacelamento da sociedade brasileira. Além disso, é interessante notar no aumento dos artigos, que seguem a tendência de estudos de obras de escritores anteriores a 1964 , aparecendo os primeiros estudos sobre poesia de resistência em 1980 por Guacira Marcondes Machado intitulado "Uma Leitura de 26 poetas hoje"3, que inicia o artigo reportando a fala de Alfredo Bosi em O ser e o tempo(1977):, o "estilo capitalista e burguês de viver, pensar e dizer se expande a ponto de dominar a Terra inteira" ( p.89). A posição da autora irá se contrapor a de Bosi, no sentido de que a tecnologia expande e não circunda o saber da humanidade, contudo ao longo do texto é possível perceber que há uma leitura do livro 26 poetas hoje de Heloísa Buarque de Hollanda, que foi publicado em 1976. Se por um lado a ficção não recebeu a mesma atenção na década entre 1968 e 1978 pela crítica universitária, o mesmo não se pode dizer do verso, pois em 1976, nomes como Antônio Carlos Secchin, Francisco Alvin, Vera Pedrosa, Antônio Carlos de Brito, compõem um primeiro esboço da Poesia Marginal.

No texto de Guacira, há a tentativa da autora de vincular os poetas citados a tradição literária brasileira, a fim de amarrar certa continuidade. Para isso ela recorre a citar Octávio Paz e Antônio Candido como a jovens críticos, que foram forjados nos anos da Ditadura. Um deles é o crítico José Guilherme Merquior. A extensão desse estudo ocorre praticamente 20 edições posteriores, quando em 2000, a revista reúne nomes como Horácio Costa e

\footnotetext{
3 Publicado na Revista de Letras número 20 de 1980, (p.89-98)
} 
Zélia Monteiro Bora,que em seus textos em parceria ou não com outros nomes pontuam uma leitura da poesia pós-64, embora não se fixem a rótulos políticos e sim a leitura teórica dos textos e de sua representação para a formação da literatura brasileira.

A revista Letras de Hoje da PUC do Rio Grande do Sul inicia sua publicação, em 1968, e percorre um trajeto semelhante às outras revistas, desenvolvendo ao longo do final da década de 1990 até o presente a opção por números temáticos ou por outros que são representantes de encontros literários, sendo que a última edição de 2008, é fruto dos estudos realizados no Congresso Internacional de Leitura e Literatura Infantil e Juvenil, que foi realizado em junho daquele ano .

A crítica universitária do final da década de 1980, que passa a ser praticada pelos anais das duas principais associações, que nascem nesse decênio: a ABRALIC, inicia como associação voltada para a Literatura Comparada em1986, na cidade de Porto Alegre( RS) e a ANPOLL, como associação de professores da pós-graduação em Letras e Linguística no ano de 1984, em Brasília(DF). Próximas em questão de datas, as duas associações irão reunir pesquisadores, cujos artigos funcionarão como sinalizadores e articuladores das pesquisas na área, que espalhadas pelo Brasil, representam em parte um painel das tendências da crítica universitária.

\section{3}

Se por um lado alguns nomes pontuaram a crítica universitária ensaística dos últimos 30 anos, nesse mesmo ninho alguns trabalhos de fôlego como os livros de Tânia Pellegrini, os de Flora Sussekind e o de Walnice Nogueira Galvão, de certa forma deram conta de inventariar a crítica literária desse período, sem contudo amarrar os fios, visto que pelo caráter ensaístico desse modelo de crítica, há dois processos que ocorrem simultaneamente, pois o crítico universitário escreve por adendo ou por sobreposição. No primeiro caso, ele não retoma uma análise anterior, se dispondo a apontar falhas, dúvidas e certezas sobre suas posições, a fim de reestruturar as suas análises, pelo contrário, ele começa de onde parou; no segundo caso, alguns pontos são retomados, contudo apenas como mote para recomeçar um novo artigo. Ambos os casos têm a mesma origem: "a falta de leitura por parte dos pares". 
A princípio antes da $W E B$, havia o empecilho da distância geográfica; depois com a pressão dos órgãos de fomento pela publicação, no sentido de manter a produção do professor universitário, a figura do crítico ensaísta aparece muito mais nas revistas eletrônicas e nas publicações impressas. Logo é possível encontrar um inventário parcial sob as tendências contemporâneas da crítica brasileira e nas dissertações e teses, que orientadas por professores ensaístas e submetidas às bancas formadas por professores que tenham certa relação com o tema

Por esse prisma é justamente em duas produções de fôlego, que foi possível traçar em linhas mais ou menos retas um estudo sobre o romance e a imprensa pós 1968. Os textos selecionados são os seguintes: O poder da imprensa na construção do escritor do Brasil contemporâneo de Alexandre Pacheco $^{4}$ e o segundo de José Reinaldo Nonnenmacher Hilário, sob o sugestivo título de $A$ maçã triangular e os romances nos anos 70: violência e resistência. ${ }^{5}$.O que aproxima as produções citadas se refere ao corpus, que tanto numa quanto noutra, os escritores tomam como ponto de referência a produção mercadológica do livro e o seu reflexo na crítica. Não é sem tempo de lembrar o que diz Walnice Nogueira Galvão em relação à crítica literária do final da década de 1970 e do início de 1980:

A crítica literária definhou( enquanto o ensaio crítico em livro cresceu); os suplementos literários desapareceram em sua maioria; o press-release, que faz parte da máquina do mercado e não da esfera da literatura, transveste a informação sobre os livros. A fórmula segura de vender obriga escritores a se repetirem, a não se arriscar[...] repetindo fórmulas usadas, [...], pois o modelo social e cultural implantado pela ditadura, solidificou sob a pressão capitalista dos mass media. Dessa forma, o retorno à democracia, traz nesse período uma nostalgia sem utopia, o que desencadeará nas décadas seguintes no encurtamento da crítica, que cada vez mais se restringe aos ensaios.(1994,p.194)

Nesse processo os jornais passam a se distanciar da crítica "acadêmica, de um modo geral, devido às transformações que estavam ocorrendo nas respectivas funções dos jornais e dos jornalistas enquanto transmissores da cultura literária diante de uma sociedade de massas a partir dos anos de 1970

\footnotetext{
4 Tese de doutoramento em sociologia pela UNESP de Araraquara-SP, defendida em 2006

5 Dissertação de mestrado defendida na UFSC, no ano de 2004
}

Caderno Seminal Digital Ano 17, nº 15, V. 15 (Jan.- Jul/2011) - ISSN 1806 -9142 
e 1980(PACHECO, 2006, p.50). O que transforma a crítica em um produto mercadológico, pois é ela que vende o livro. O processo de substituição, se assim pode chamar do momento em que os jornalistas os "focas" que vinham de formação em Letras, Direito, Ciências Sociais, enfim acadêmicos eu por notoriedade influenciam a escolha do leitor, pelo jornalista de formação universitária surge gradativamente, "sobretudo a partir dos anos de 1970, da figura do jornalista que passou a se apropriar das análises sobre a literatura e o autor literário, dentro das funções do chamado jornalista personalizado "(p.5152). O jornalista de formação que irá substituir o literato, aquele herdeiro do scholars, cuja formação e especialidade estava sendo sobreposta por um novo tipo de crítico: o jornalista, que muitas vezes lia partes do livro ou era convencido pela editora a avaliar positivamente ou não uma determinada obra.

Assim, de acordo com Flora Sussekind não teria ocorrido somente uma tensão metodológica que arcou os anos de 1960 e 1970, a partir das influências dessas linhas, mas teria ocorrido também uma hesitação por parte da crítica universitária subseqüente a Afrânio Coutinho e Antonio Candido relacionada à produção de textos, ora próximos do tratado, ora próximos do ensaísmo.(p.95)

que por sua natureza teórica, muitas vezes afastava o leitor comum. O resultado é que a crítica especializada, formada por professores universitários enfrentasse três tipos de problemas sérios a partir da década de 1970. Por um lado a indústria cultural, avançava sobre os meios de comunicação, selecionando o que o brasileiro deveria ler, ver e ouvir. Por outro o mercado editorial mais interessado em promover os livros do que vê-los analisados sob a lua de uma cultura literária, que no Brasil já se firmara. E por fim a crítica literária teve de enfrentar uma imprensa mais preocupada em impor a partir das influências da chamada indústria cultural, um modelo de leitura de obras realizada por jornalistas de formação. "que passaram a realizar análises superficiais, generalizadoras e a estarem empenhados na sensacionalização de determinados aspectos e de certos valores contidos nas obras literárias, bem como também realizarem a sensacionalização de seus autores"(p.98). Dessa forma a crítica universitária como já analisamos anteriormente transformou-se em uma crítica ensaística e migrou para as revistas universitárias onde permanece até hoje. 
Um braço se assim, pode-se dizer, a partir do final da década de 1980 , cava, nas páginas internas dos jornais, um espaço, no qual a crítica universitária produz um tipo de texto híbrido entre o ensaio e a matéria jornalística em suplementos literários ${ }^{6}$, que ao longo da nossa pesquisa demonstraram a inexistência de análises que abordassem a obra de escritores como é o caso de João Ubaldo Ribeiro. Na maioria desses suplementos há uma ocorrência de estudos, que ora retomam escritores canônicos, ora apresentam teóricos como Derrida, Bakhtin, os formalistas russos, Walter Benjamim, Adorno, entre outros. A maioria dos suplementos não analisa obras de escritores contemporâneos às décadas de 1980 e 1990, exceto o caso de $O$ Galo. O restante aprofunda-se até nas questões de estética das artes plásticas, menos em ler os escritores brasileiros.

O meio termo entre a crítica jornalística, voltada para a exploração de todos os aspectos relativos ao autor e a publicação da obra com títulos sensacionalistas, que pretendem atrair o leitor para comprar o livro, enquanto mercadoria, e a crítica universitária dos suplementos, que tenta ser uma "pérola" no meio do jornal,oferecendo ao leitor uma visão mais catedrática das artes, mas no entanto distanciada dos acontecimentos literários do presente, está na criação de duas revistas: a Cult e a Bravo, cujas matérias transitam entre a indústria cultural e os estudos acadêmicos. No primeiro caso abre-se espaço para a produção literária, fora do mercado editorial, em cujas páginas figuram poemas, contos, capítulos de livros de novos escritores ou outros, que não figuram na mídia. Não obstante, escritores laureados pela indústria cultural e pelo mercado editorial como João Ubaldo Ribeiro e Paulo Coelho têm suas obras analisadas e apresentadas ao público. Ao lado desses há dossiês sobre Machado de Assis, Borges, Adorno, Derrida. Vence nesse caso os integrados. No segundo caso, a revista é mais voltada para um público, que usufrui da alta cultura como festivais de teatro, exposição das artes visuais, feiras de livros e prêmios do cinema. A esse público é oferecida uma revista com matérias e visuais muito chamativos, sem, contudo serem extravagantes, o que agrada aos olhos dos menos versados. Logo a Bravo constituiu um status de alta 
cultura para os que aspiram a estarem "bem" informados e representam mais um braço dos mass media para os apocalípticos.

Somente um texto tão rico como o de Pacheco, faria com que após lê-lo, as asas do estudo sobre a crítica pudessem pousar além das expectativas iniciais do texto, estendendo até pontos de contato ou não entre as duas críticas: a jornalística e a universitárias, bem como os pontos de distanciamento entre elas demarcados por um momento histórico, no qual a indústria editorial do livro, a indústria cinematográfica e a indústria fonográfica reinaram sobre 0 mercado, quando livros eram publicados aos milhões, filmes enchiam as bilheterias dos cinemas; discos, fitas e CDs orbitavam sobre as nossas cabeças. O declínio desse período iniciou com o final da década de 1980 e a de 1990, quando os filmes passaram a serem exibidos em vídeo-cassete e as fitas cassete podiam ser gravadas em aparelhos de som. Pronto, espalhou-se sobre a terra a "pirataria" para muitos e "genéricos" para outros, mas o resultado é o mesmo, pois aqui e ali filmes e músicas eram copiados e distribuídos. Um dique foi construído com os nomes de DVD e CD, que a princípio não eram violados e graváveis, mas em menos de cinco anos, eles passaram a ser o alvo das indústrias piratas, que em feiras e camelôs vendem entretenimento a preços irrisórios. Além disso, o computador, que não era um item doméstico, nos primeiros 8 anos do século XXI passou a sê-lo. Junto a ele, os notebooks, os palmtops, os celulares, os MPs multiplicados em dois anos de 3 até o 10, hoje são celular, gravador,câmera de vídeo e fotográfica, televisão, computadores e DVD. Os filmes, músicas e canais de TV podem ser acessados e baixados. Assim como é possível fazer compras em qualquer lugar do mundo sem sair de onde a pessoas estiver.

\section{4}

E quanto ao livro? Esse anda com os dias contados, ainda não ocorreu, porque o público consumidor de livros, ainda tem aquele mesmo apego ao objeto livro, ao papel impresso, mas essa geração arraigada, aos poucos está descobrindo a WEB e com ela um recurso, que os atrai muito mais que o livro, o zoom. Isso mesmo aquele recurso que multiplica o tamanho das letras em muitas vezes e faz com que a geração dos "cansados das vistas" possa ler com mais facilidade. Outro fator também consiste na questão do protecionismo 
da produção intelectual, que evita ao máximo o plágio, visto que o texto não circula como a música, que um escreve, outro coloca as notas musicais e muitos e muitos outros gravam.

No livro seja ele em prosa, verso, ensaio ou teórico, há a presença do autor, mas mesmo dessa forma nada está impedindo, que livros sejam digitalizados na íntegra com autorização das editoras ou não. Um dos métodos utilizados para burlar são os blogs, que por sua natureza de rizoma,onde não é possível o acesso a não ser que se adentre um a um, para encontrar um sistema, no qual boa parte dos livros estão digitalizados..Os métodos para burlar os mecanismos de proteção estão cada vez mais sofisticados com programas, que transformam qualquer texto legível no formato Word. Daí para frente é só copiar.

José Reinaldo Nonnenmacher em A maçã triangular e os romances nos anos 70: violência e resistência faz um estudo sobre o comportamento da crítica após 1964, num formato, que mais se aproxima dos estudos literários do que o texto de Pacheco, vindo a complementar tudo o que vem sendo desenvolvido ao longo deste capítulo.

Haja vista que, do mesmo modo como a literatura, a critica literária passava por transformações importantes após o ano de 1964, que representa um verdadeiro divisor de águas da cultura nacional.[...]A crítica de esquerda, como a pretendida por Georg Lukács, em contraposição à crítica Formalista e Estruturalista, começava a tomar corpo entre nossos críticos mais destacados, e entre as principais instituições formadoras do pensamento nacional, como a USP e a PUC, novas perspectivas se abriam. A crítica assumiu francamente um papel também vinculado a uma ideologia. Apesar da difusão da crítica marxista, estudos dialéticos de maior relevância só seriam realizados após 1970. É esse "galho" da crítica, cujo broto é Antonio Candido, que nos interessa.(p.12-13)

Apesar de ser um "broto" muito importante e interessar para os nossos estudos, o que mais o aproxima do pensamento que se delineia situa-se na confirmação, que como um orbes Candido circunda os textos que vêm sendo construído nesta tese. Visto que o texto de Letícia Mallard,já citado, separou de alto abaixo os críticos brasileiros, de acordo com a ideologia de não posicionálos politicamente em esquerda ou direita, mas de discutir o fazer crítico brasileiro em relação à corrente crítica assumida por cada grupo. Assim sendo à medida que um grupo era formalista, outro, estruturalista, outro aninhava o 
pós-estruturalista e por fim a tendência de classificar a crítica brasileira a partir da idéia dos anos 40 , século $X X$, sob a formação da crítica de rodapé e dos scholars.

A presença de dois tipos de crítica: a de rodapé e a dos scholars, que nos anos de 1940, se contrapuseram porque a primeira era exercita por "bacharéis" de direito e por outros formados ou não, que do final do século XIX até a década de 1940 traduziam via crítica a visão sobre a produção literária brasileira. Visto dessa forma simplista parece que não se justificaria a oposição dos scholars, afinal a crítica é um juízo de valor,sendo pois liberada a qualquer um, entretanto não é bem assim, pois a partir da criação das faculdades de Letras, havia a necessidade de afirmar a disciplina Literatura, por três motivos: primeiro para que essa não ficasse embutida nos estudos de Língua Portuguesa; segundo porque as teorias dos formalistas, que embora deslocada no tempo, vêm influenciar os professores e estudantes de Letras da década de 1940 em diante, pois essa crítica pedia um estudioso( crítico) especializado.E por último era uma questão de espaço na mídia( jornal), pois o território, que até então era ocupado por "bacharéis".

No caso da crítica após 1964, ela ocorre pela presença dos escritores no jornais, pois romancistas e poetas passam a escrever nas colunas dos jornais.Na maioria, esses críticos não são formados em Letras, não são especialistas, visto dessa forma, mas têm prática no fazer literário. Com o tempo eles e outros, que são jornalistas por formação ou "focas" passam a fazer a crítica literária, voltando ao modelo do crítico de rodapé.

Com o término do período da Ditadura Militar, ao longo dos anos 80 , os nomes que estavam exilados, em atividade ou no anonimato, arregimentam um exército em prol de um processo de reconstrução de um país. Reconstruir não é fácil, principalmente quando são muitas mentes pensando e o escritor, após conviver muito tempo nos jornais, assimilou as idéias de produto-venda-renda. No final do processo, o escritor, não era mais um homem de letras, mas sim um homem de mídia, que para vender o seu livro independente da qualidade ou não necessita de uma crítica de primeiras horas, que geralmente era feita por seus pares dos jornais. Muitos dos jornalistas eram de formação e quase ou anda se interavam sobre crítica literária. Dessa forma houve o aumento da 
crítica de rodapé, pois os jornalistas não precisavam de uma formação em Letras para discutir uma obra, nem tão pouco de serem estudiosos do assunto, eles nem mesmo precisam ler a obra. O que interessava e ainda interessa é a editora que está publicando e se o livro possui característica como: um enredo que agrade a um determinado público, um material gráfico que atenda aos padrões mínimos e que a fórmula de marketing usada desde o momento de criação atenda ao mercado editorial. Logo o bom livro é aquele que: autor consagrado, modelo encomendado, linguagem de fácil acesso e enredo interessante.

Assim a crítica de rodapé, no Brasil, incorpora dois tipos de crítica: a de autores e a jornalística, enquanto que a dos scholars, a universitária, que demorou muito a tomar a sua posição de mediadora entra a obra e o público. 0 atraso custou muito, pois mais de uma geração passou após 1964 e uma cultura midiática já estava formada, restringindo o fazer crítico universitário a alguns suplementos literários como o MAIS, LEIA e Caderno de Cultura, que figuram dentro dos jornais a partir do final da década de 1980. Seria até interessante, se nesses suplementos, os críticos, na maioria professores universitários tivessem atualizado os seus tópicos de discussões sobre as obras publicadas nas décadas seguintes. Salvo raras exceções como alguns números do LEIA, que foram dedicados a autores contemporâneos, o restante evita ao máximo os nomes considerados como da "cultura de massa".

Dois movimentos surgem desse processo: um relativo ao formato do texto crítico; outro quanto ao status da crítica. No primeiro caso o texto crítico se assemelha a uma nota de jornal para as obras integradas à cultura de massa e sob a batuta do mercado editorial; ou o texto crítico migra cada vez mais para o formato do ensaio e fixa nas revistas literárias das universidades. No caso das obras integradas e de seus autores são as revistas de grande circulação como a Veja, Isto é ,Manchete, Época, que detêm a indução do gosto do leitor. É interessante notar que a Veja devido a sua divulgação e a sua idade, é a que mais influenciou no gosto do leitor, sendo que nomes como José Aderaldo Castelo aparecem esporadicamente na década de 1980, sendo que no decorrer dos próximos anos, a tendência da seleção dos artigos passa para a mão de nomes como de Carlos Graeb e Ney Biachi.Os jornais desse período 
como O Globo, A Folha, O Estado de São Paulo seguem o mesmo padrão.Quanto aos ensaios, eles passam a se fixarem nas revistas universitárias, como já dissemos, migrando uma vez ou outra para os suplementos literários, mas sempre mantendo distância daquelas obras, que "cheiravam" a massificação. O autores dos ensaios, na maioria das vezes assumem uma tendência apocalíptica, cujo freio parecia estar num constante retrocesso a obras canônicas ou a publicações( obras) que estivessem a margem do mercado editorial, cujos textos mais se aproximam do ideal da alta literatura.

No segundo caso quanto ao status da crítica delimita-se bem cada uma a partir das preferências: uma a universitária, que como um condor lança suas sombras sobre alguns autores contemporâneos, ao capturarem características que atendam em parte ou não aos requisitos da alta literatura, e a outras como Flora Sussekind classifica como sendo a de rodapé, que pressa a um compromisso editorial dita os livros, que serão os mais vendidos ou divulga aqueles que serão os mais vendidos, isso no caso dos livros de autores brasileiros. No caso do mercado estrangeiro, já há uma cópia a ser reproduzida, pois se serviu para o público dos EUA e da Europa, porque não será bom para os "tupiniquins".

\section{5}

No decorrer dos estudos sobre a crítica entre a década de 1960 do século $X X$ e a primeira década do século $X X I$, pode-se considerar um período muito extenso, que após muitas leituras, percebeu-se que não há uma linha de estruturação e nem tão pouco textos( artigos, ensaios ou livros) que abordem a temática de uma forma ampla e livre de conceitos políticos. Há ensaios como o de Regina Zilberman e Luiz da Costa Lima, que atendem a questão da divisão histórica e da percepção de uma leitura da influência tanto da indústria cultural quanto da política editorial brasileira sobre a produção literária desse período. Outros nomes como de Walnice Nogueira Galvão se situam mais na relação do mercado editorial em relação a determinados escritores. Ainda há um terceiro grupo, no qual se situam Tânia Pellegrini e Flora Sussekind.

A produção ensaística crítica de Tânia Pelegrini tende para uma avaliação da produção literária em escalas diferentes em primeiro momento 
antes da abertura da década de 1970 e depois desse período numa leitura que focaliza somente as obras de autores brasileiros, na tentativa de estabelecer uma aproximação com uma História Literária Brasileira. No caso de Flora Sussekind e por seus textos figurarem entre o ensaio e o texto jornalístico, visto que muito do seu trabalho, na década de 1990 foi publicado em suplementos, talvez seja o mais próximo de uma atualização da crítica literária das três últimas décadas do século XX. Por outro lado e para finalizar há o trabalho de Letícia Mallard, já citado, que se prendeu a nomes da Academia Brasileira de Letras, que fazem parte do panteão dos imortais, sem se aprofundar em uma pesquisa crítica mais geral. Logo nem um trabalho dos citados pode ser considerado conclusivo. O que se percebe em todos os casos citados é a contribuição de cada um para um painel da crítica em aberto, pois não há uma articulação entre esses críticos. É como se cada um visse o objeto( a crítica) sob um prisma, sem perceber as outras visões que o outro poderia ter.

Portanto, a nossa ver, a crítica literária brasileira da década de 1960 até o início do século XXI, pode ser dividida de forma didática da seguinte forma.

1964 -1974 O crítico universitário discute as obras literárias do passado sob a luz de teorias marxistas e estruturalistas. A influência de Walter Benjamin é sentida quanto à indústria cultural e a reprodução da obra de arte, que caminha a passos largos num país chamado Brasil, cuja produção cultural sob a batuta da Ditadura de 1964, passa a importar padrões estrangeiros ou a se resguardar em alguns guetos. $\mathrm{O}$ que por sua vez faz com que os textos dos críticos literários desse período desloquem-se do momento presente para o passado, a fim de analisarem obras canônicas como forma de preservar a erudição em relação à avalanche da cultura de massa, que os meios de comunicação: televisão e cinema integrados à indústria cultural divulgam em seriados, novelas e os "enlatados" americanos uma forma de entretenimento, que mantêm a população pacífica, em sua casa, ligada ao sistema. No outro lado o crítico de jornalista e o artista divulgam um bom número de obras, sempre se prendendo à análise comparada entre 
a obra recém publicada e alguma ligação com outras engajadas pelo viés da estrutura do texto.

1975-1985 - O momento histórico foi marcado, em uma década, para que em passos lentos ocorresse a abertura política e a anistia. O que trouxe de volta ao Brasil não só os exilados, mas uma forma engajada de ver a literatura, pois como o livro, era de uma circulação mínima, ele foi o único veículo, que não sofreu tanta censura, logo residia nele um novo espaço a ser explorado pelo mercado editorial.Nunca se vendeu tantos livros no Brasil como nesse período. A leitura se tornou uma forma de reencontro com o passado tanto dos que ficaram como dos que foram embora. São as histórias vividas, mitigadas, que vão do rural para o urbano; do urbano ao infanto-juvenil; do romance regionalista à ficção científica.A crítica não se distanciou da posição assumida anteriormente, contudo há um bom número de teóricos como José Aderaldo Castelo, Wilson Martins, Cremilda Medina e Guilherme Merquior, que passam a fazer uma crítica literária mais atualizada em jornais e revistas, que em termos dão legitimidade a certos nomes como o de João Ubaldo Ribeiro.

1986- 1996- Passado a fase do engajamento e da releitura da história do passado recente, a crítica volta-se para a leitura do passado acumulado em ruínas, das quais num processo de leitura ideológica será possível ao crítico ler a obra de arte( literatura) e a sociedade brasileira. As leituras da crítica assumem dois fenômenos, que podem ser explicado pela biologia, visto que algumas obras são acasuladas e outras mumificadas. No primeiro caso, Benjamin, diz que as múltiplas leituras de um texto literário com o decorrer do tempo o transformam em outra coisa, ou seja, de larva em borboleta. No segundo, as leituras críticas mumificam um texto, a fim de que seu estado permaneça sempre o mesmo, impossibilitando qualquer outro tipo de leitura. Quando um texto é lido como engajamento, ele passa por um processo de mumificação ideológica,visto que o engajamento não restringe apenas a questão de oposição política, mas também da assimilação do mesmo a uma função histórica. Dessa forma o texto( a obra literária) mesmo não perdendo as 
primeiras camadas, que the foram impingidas, ao longo da história literária da obra, outras leituras aderem à camadas, tornando a obra literária algo bem diferente do que ela propunha a princípio.Nesse período histórico, a crítica literária acasula, mumifica ou até utiliza dos dois processos selecionando obras, que constituirão o novo cânone, a ser lido e relido especialmente pela crítica universitária.

1997 até 2007 - A profissionalização do crítico científico e institucional ocorre de acordo com o local da instituição a qual ele pertença, seja o jornal, a revista ou a universidade determinará a forma com que uma obra possa ser analisada. Contudo sempre haverá um ponto em comum: a fórmula garantida, ou seja, manter o cânone estabelecido na fase anterior, salvo raras exceções quando um autor regional entra no círculo universitário ou um escritor brasileiro com record de vendagem, que passa a ser objeto da crítica jornalística.No caso da crítica de artista, essa diminui sua atuação quanto mais o mercado editorial passa a ficar apertado na questão de espaço de publicação. A análise da literatura passa a seguir determinadas regras, que foram sendo construídas ao longo da história daquela instituição ou por força da indústria cultural.O papel do crítico situa-se entre um reprodutor de resenhas e um "chancelador" de autores na pesquisa universitária.

A crítica literária, no Brasil, nas últimas décadas do século XX e início de $X X I$, se profissionalizou com ensaios críticos, que acompanhavam a produção dos escritores: ora analisavam obras com sentido de dar certa contribuição à sociedade brasileira, ora atendiam aos anseios do mercado editorial. Independente do lado ao qual cada um dos tipos de crítica se filiou, o que é possível observar é que nunca se fez tanto juízo crítico, sem a pretensão de dizer, que estava se fazendo crítica literária. Pois ensaios, artigos, colunas nos jornais, pequenas resenhas, comentários nas laterais dos jornais ou no rodapé, as "orelhas" dos livros, espaços reservados nas revistas de grande circulação, artigos em anais de congressos, tudo contribui para que qualquer pesquisador de fortuna crítica encontre um vasto material, no qual o único tópico é o juízo de valor sobre determinado autor. 


\section{Referências bibliográficas}

BOSI, Alfredo. Dialética da Colonização. São Paulo: Companhia da Letras, 1998.

1999.

História concisa da literatura brasileira. 36. ed. São Paulo: Cultrix,

CAIRO, Luiz Roberto. "Nota sobre o cânone da história da Literatura Brasileira na virada dos séculos."In: OLIVEIRA, A M D; ESTEVES, A R. e CAIRO, R.V. ( orgs) Estudos Comparados de Literatura. Assis: FCL/ UNESP, 2005

CANDIDO, Antonio. Formação da Literatura Brasileira:momentos decisivos. 6.ed. Belo Horizonte: Itatiaia, 2000.-UEMS

"Preconceito e democracia." Remate de Males. São Paulo: Humanitas, 2000. Ano 1.n. 13.

. Educação pela noite e outros ensaios. 2 ed. São Paulo: Ática, 1984.

. Literatura e Sociedade. 8.ed São Paulo : Publifolha, 2000.

MALARD, Letícia. $\mathbf{1 1 0}$ anos de crítica literária. Disponível em http://www.academia.org.br/abl/media/RB52\%20-\%20PROSA-03.pdf ；2007, p.115-128.

MORIN, Edgar. A integração cultural. In:

Cultura de massa no século XX: o espírito do tempo - I- neurose. 4.ed. Rio de Janeiro: ForenseUniversitária, 1977.

SÜSSEKIND, Flora. Agora sou profissional. Literatura e Vida Literária Rio de Janeiro: Zahar, 1985. $\overline{09 / 1986}$.

Mais virão virão.Folha de São Paulo: Leia São Paulo, n. 95,p.18, $\overline{\mathrm{CL}, 1990 .}$

Figurações do narrador. O Brasil não é longe daqui.São Paulo:

Ficção 80: dobradiças e Vitrines.. Rio de Janeiro: Ed. UFRJ, 1993. jul. 2000.

A literatura brasileira dos anos 90. Folha de São Paulo: MAIS. 23 de

.. Escalas e ventríloquos. Folha de São Paulo: Mais. 23/07/2000. p. 5-

11.

TADIÉ, Jean-Yves. A crítica no século 20. Trad. Wilma Freitas Ronald de Carvalho. 5.ed. Rio de Janeiro: Bertrand, 1992.

TRAVANCAS, Isabel. O livro no jornal. Cotia: Ateliê, 2001. 